\title{
Transition Metal Catalysis in the Generation of Petroleum and Natural Gas
}

DE-FG05-92ER14295

Frank D. Mango

Department of Chemical Engineering

Rice University

Houston, TX 77251-1892

Final Report

January 21, 1997

\section{RECEIVED \\ FEB 06 1997 \\ OSTI}

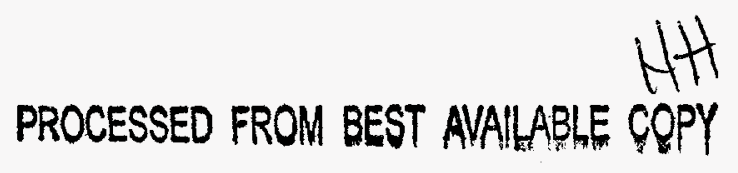

DISCLAIMER

This report was prepared as an account of work sponsored by an agency of the United States Government. Neither the United States Government nor any agency thereof, nor any of their employees, makes any warranty, express or implied, or assumes any legal liability or responsibility for the accuracy, completeness, or usefulness of any information, apparatus, product, or process disclosed, or represents that its use would not infringe privately owned rights. Reference herein to any specific commercial product, process, or service by trade name, trademark, manufacturer, or otherwise does not necessarily constitute or imply its endorsement, recommendation, or favoring by the United States Government or any agency thereof. The views and opinions of authors expressed herein do not necessarily state or reflect those of the United States Government or any agency thereof. 


\section{DISCLAMMER}

Portions of this document may be illegible in electronic image products. Images are produced from the best available original document. 


\title{
Relevant Reprints Attached
}

Mango, F. D. (1992) Transition metal catalysis in the generation of petroleum and natural gas. Geochim. Cosmochim. Acta. 56, 553-555.

Mango, F. D. (1992) Transition metal catalysis in the generation of petroleum: A genetic anomaly in Ordovician oils. Geochim. Cosmochim. Acta. 56, 3851-3854.

Mango, F. D., Hightower, J. W., and James, A. T. (1994) Role of transition-metal catalysis in the formation of natural gas. Nature 368, 536-538.

Mango, F. D. (1994) The origin of light hydrocarbons in petroleum: Ring preference in the closure of carbocyclic rings. Geochim. Cosmochim. Acta. 58, 895-901.

Mango, F. D. (1996) Transition metal catalysis in the generation of natural gas. Org. Geochem. 24, 977-984.

\begin{abstract}
This project originated on the premise that natural gas could be formed catalytically in the earth rather than thermally as commonly believed. The intention was to test this hypothetical view and to explore generally the role of sedimentary metals in the generation of light hydrocarbons (C1 - C9). We showed the metalliferous source rocks are indeed catalytic in the generation of natural gas. Various metal compounds in the pure state show the same levels of catalytic activity as sedimentary rocks and the products are identical. Nickel is particularly active among the early transition metals and is projected to remain catalytically robust at all stages of catagenesis. Nickel oxide promotes the formation of n-alkanes in addition to natural gas (NG), demonstrating the full scope of the hypothetical catalytic process:

$$
\mathrm{n}-\mathrm{C}_{\mathrm{x}}=\stackrel{\left[\mathrm{NiO}^{*}\right]}{\mathrm{H}} \stackrel{\mathrm{H}}{\rightarrow} \mathrm{NG}+\mathrm{n}-\mathrm{C}_{5}+\mathrm{n}-\mathrm{C}_{6}+\ldots \mathrm{n}-\mathrm{C}_{\mathrm{x}-1}
$$
\end{abstract}

The composition of catalytic gas duplicates the entire range of natural gas, from so-called wet gas to dry gas ( 60 to $95+\mathrm{wt} \%$ methane), while gas generated thermally is consistently depleted in methane ( 10 to $60 \mathrm{wt} \%$ methane). These results support the view that metal catalysis is a major pathway through which natural gas is formed in the earth. 


\section{INTRODUCTION}

The concept that non-biogenic natural gas is thermolytic has remained almost unchallenged for nearly half a century (Tissot and Welte, 1984; Schoell, 1980). Disturbing contradictions exist, however: oil is found at great depth, at temperatures where only gas should exist (Price, 1993) and oil and gas deposits show no evidence of the thermolytic debris indicative of oil decomposing to gas (Mango, 1987). Moreover, oil and kerogen pyrolysis typically produces between 10 and $60 \%$ wt methane (in $\mathrm{C}_{1}-\mathrm{C}_{4}$ ) (Horsfield et al., 1991; Hikita et al., 1989; Espitalie et al., 1987; Saxby and Riley, 1984; Evens and Felbeck, 1983; McNab et al., 1952) while natural gas contains between 60 and $95+\%$ methane (Hamak and Sigler, 1991). $n$-Alkanes give 6 and $13 \%$ methane at 600 and $700^{\circ} \mathrm{C}$, respectively (Fabuss et al., 1962; Appleby et al., 1947). Continued cracking of $\mathrm{C}_{2}-\mathrm{C}_{4}$ hydrocarbons produces drier gas (Horsfield et al., 1991), but the relevance of these results to geologic conditions is unclear given the extraordinary stability of these light hydrocarbons. Propane, for example, has a half-life of $\sim 8 \times 10^{8}$ years at $200^{\circ} \mathrm{C}$ (Laidler et al., 1962). It has been suggested that natural gas becomes enriched in methane through fractionation during migration (Price and Schoell, 1995). However, there is little evidence supporting fractionation as an explanation for the high concentrations of methane seen in produced gas.

Natural gas could be catalytic, promoted by the transition metals in carbonaceous sedimentary rocks (Mango, 1992). According to this hypothesis, olefins (n- $\mathrm{C}^{-}$) and hydrogen, generated from decomposing kerogen $(\mathrm{K})$, react with active metals $\left(\left[\mathrm{M}^{*}\right]\right)$ yielding gas $(G)$ enriched in methane through the catalytic cycle shown in Fig. 1:

$$
\mathbf{K} \rightarrow\left[n-C^{=}+\mathrm{H}_{2}\right] \stackrel{\left[M^{*}\right]}{\rightarrow} \mathbf{G}
$$

This concept gained serious attention when metalliferous source rocks, hydrogen and olefins were reported to catalytically generate gas identical to natural gas in isotopic and molecular composition (Mango et al., 1994). Although the source rocks were indeed catalytic, the role of transition metals was unclear, and it has been argued that they were probably not the catalytic agents (McNeil and BeMent, 1996). The objective here is to demonstrate that pure transition metal compounds, in the absence of source rocks, carry out the same catalytic reaction as seen in source rocks. It must be shown that they are indeed catalytic, exhibiting the fundamental characteristics of catalytic reactions: enhanced reaction rates, high specificity to certain products, and indefinite lifetimes. Attention is focused on the early transition metals, particularly nickel and vanadium which are known to be major components of carbonaceous sedimentary rocks (Tissot and Welte, 1984).

\section{EXPERIMENTAL}

All reactions were carried out in glass U-tubes $(6 \mathrm{ml})$ fitted at each end with stopcocks and septa. Chromatography was carried out using Hewlett-Packard 5890 
Series II unit with a $60 \times 0.53 \mathrm{~mm}$ i.d. fused silica capillary column (SPB-1, Supelco): $70^{\circ} \mathrm{C}, 7 \mathrm{~min}$, then $7^{\circ} \mathrm{C} / \mathrm{min}$ to $250^{\circ} \mathrm{C}$.

Metal Porphyrins: Nickel and Vanadyl etioporphyrins were obtained from Strem Chemical and used without further purification. Nickel etioporphyrin $(0.114 \mathrm{~g}), n$ octadecene-1 (0.2 ml; Johnson Matthey, 92\%) and hydrogen (1 atm) reacted in a closed reactor for 20 hours at $150^{\circ} \mathrm{C}$ and in another reaction for 25 hours at $200^{\circ} \mathrm{C}$. Silica gel $(0.5 \mathrm{~g}$, Aldrich, Grade $22,60-200 \mathrm{mesh}$, unactivated $)$, nickel etioporphyrin $(0.114 \mathrm{~g})$ and $n$-octadecene- $1(0.2 \mathrm{ml})$ were heated at $150^{\circ} \mathrm{C}$ in a closed reactor under hydrogen for 22 hours. Vanadyl etioporphyrin $(0.48 \mathrm{~g})$, silica gel $(0.5 \mathrm{~g})$, and $n$-octadecene- $1(0.2 \mathrm{ml})$ reacted in hydrogen at $150^{\circ} \mathrm{C}$ for 4 days. All products were analyzed by gc using a standard mixture of methane in hydrogen $(0.5 \mathrm{~mol} \%$ methane; Iweco, Inc) for quantitative analysis.

Metal Acetylacetonates: The metal acetylacetonates in Table 1 were obtained from Aldrich ( $95 \%$ purity) and used as received without further purification. Metal compounds $(\sim 1 \mathrm{~g})$ were reacted with $n$-octadecene- 1 or $n$-dodecene- $1(0.2 \mathrm{ml})$ in glass U-tubes. In a typical reaction, nickel acetylacetonate $(0.89 \mathrm{~g})$ was heated in flowing hydrogen $(\sim 1$ $\mathrm{ml} / \mathrm{min}$ ) for 24 hours at $200^{\circ} \mathrm{C}$. The temperature was then lowered to $150^{\circ} \mathrm{C}, n$-dodecene1 added $(0.2 \mathrm{ml})$ and the closed reactor containing metal acetylacetonate, olefin and hydrogen allowed to stand for several days. Reactions were carried out at 150 and $200^{\circ} \mathrm{C}$. All reactions were heterogeneous with liquids (olefin) and gas (hydrogen) reacting with a solid catalyst. No attempt was made to maximize reaction rates by physically dispersing the catalyst to promote metal exposure. The reaction rates in Table 1, therefore, should be viewed as lower limits.

Nickel Oxide (NiO): Hydrogen (1 atm; $1 \mathrm{ml} / \mathrm{min}$ ) was passed over nickel oxide $(2.46 \mathrm{~g}$ powder; Baker Reagent $(99.5 \%)$ ) in a U-tube at $350^{\circ} \mathrm{C}$ for 24 hours. Olefin was then added ( $n$-dodecene- 1 or $n$-octadecene-1, $0.2 \mathrm{ml}$ ) and the mixture heated $\left(200^{\circ} \mathrm{C}\right.$ ) in a closed reactor under hydrogen ( $1 \mathrm{~atm}$ ) for several days. Four reactions were carried out under steady-state conditions by injecting excess olefin through the gas-inlet side of the reactor under hydrogen flow at $0.45 \mathrm{ml} / \mathrm{min}$ ( $\pm 0.01 \mathrm{s.d}$.). Gas effluents were monitored by gc analysis until steady-state conditions were achieved (until product compositions were constant over time) whereupon rates were determined by multiple gc analyses using a gas standard ( $0.5 \mathrm{~mol} \%$ methane in hydrogen) for quantitative analysis.

Nickel Oxide/Silica Gel: Nickel oxide dispersed on silica gel was prepared by dispersing nickel nitrate on silica gel and then thermally decomposing the nitrate to nickel oxide (Bhattacharyya and Vir, 1957). A solution (150 ml) of nickel (II) nitrate (hexahydrate) (4.8 g; Aldrich) was added to $100 \mathrm{ml}$ silica gel (60-100 mesh) and the resulting mixture evaporated to a thick slurry at $\sim 70^{\circ} \mathrm{C}$ and then oven-dried in air for 24 hours $\left(\sim 80^{\circ} \mathrm{C}\right)$. To reduce the nitrate to the oxide, the product was heated under flowing hydrogen at $400^{\circ} \mathrm{C}$ for 24 hours. These conditions $\left(400^{\circ} \mathrm{C}\right.$ for 24 hours) were arbitrary but sufficient to produce an active catalyst of the assumed composition $\mathrm{NiO} / \mathrm{SiO}_{2}(2.6 \% \mathrm{wt} \mathrm{Ni})$. It is doubtful that complete reduction to zero-valent Ni occurred since activity was unaffected by the addition of oxygen or water. Steady-state experiments $\left(1.06 \mathrm{~g} \mathrm{NiO} / \mathrm{SiO}_{2}\right)$ were carried out between 180 and $210^{\circ} \mathrm{C}$ by injecting excess $n$-octadecene- $1(0.2 \mathrm{ml})$ through the septum on the gas-inlet side of the reactor (hydrogen flow $=1.14 \mathrm{ml} / \mathrm{min}$ ) and then monitoring the effluent by gc analysis until steady-state condition were achieved. One 
olefin injection was usually adequate to maintain steady-state conditions for several hours. Rates of product generation were determined through triplicate gc analyses. The effects of various poisons were studied under steady-state conditions $\left(200^{\circ} \mathrm{C}\right)$ by injecting water $(\sim 0.2 \mathrm{ml})$, air $(\sim 3 \mathrm{ml})$, or $\mathrm{CO}_{2}(\sim 3 \mathrm{ml})$ into the gas stream through the inlet septum. The effects of $\mathrm{CO}$ were tested by replacing pure hydrogen as the flowing gas with hydrogen containing $5 \% \mathrm{CO}$ in the reaction: $\mathrm{NiO} / \mathrm{SiO}_{2}+n$-octadecene- $1,200^{\circ} \mathrm{C}$, steady-state with gas flow $=1 \mathrm{ml} / \mathrm{min}$.

Nickel Sulfide (NiS): The reaction with $\mathrm{NiO}$ and $n$-dodecene-1 was repeated using NiS at $200^{\circ} \mathrm{C}$ for several days.

Silica Gel $\left(\mathrm{SiO}_{2}\right)$ : Silica Gel (1.2 g; Aldrich, Grade 22, 60-200 mesh), preheated in flowing hydrogen at $350^{\circ} \mathrm{C}$ for 1 hour, and $n$-dodecene- $1(0.2 \mathrm{ml})$ were heated under hydrogen for several days at 150 and $200^{\circ} \mathrm{C}$ in a closed reactor and the products analyzed by gc using a standard gas mixture ( $0.5 \mathrm{~mol} \%$ methane in hydrogen).

\section{RESULTS AND DISCUSSION}

Porphyrins, first identified in fossil fuels over half a century ago (Treibs, 1934), are ubiquitous in petroliferous sediments and a major reservoir of transition metals in petroleum (Yen, 1975). Nickel etioporphyrin was analyzed for catalytic activity and found to be only moderately active in the conversion of n-octadecene- 1 and hydrogen into light hydrocarbons, giving $3.3 \times 10^{-3} \mathrm{~g} \mathrm{CH}_{4} /\left(\mathrm{mol} \mathrm{Ni}\right.$ day) at $200^{\circ} \mathrm{C}$ with $20 \%$ (by weight) $\mathrm{C}_{1}$ in $\mathrm{C}_{1}-\mathrm{C}_{4}$. Activity increased sharply in the presence of silica gel, which by itself shows very low activity under the same conditions: at $150^{\circ} \mathrm{C}, \mathrm{Ni} / \mathrm{SiO}_{2}$ gives $3.4 \times 10^{-3} \mathrm{~g}$ $\mathrm{CH}_{4} /\left(\mathrm{mol} \mathrm{Ni}\right.$ day) with $86 \% \mathrm{C}_{1}$ in $\mathrm{C}_{1}-\mathrm{C}_{4} ; \mathrm{SiO}_{2}$ gives $3.0 \times 10^{-8} \mathrm{~g} \mathrm{CH} 4 /\left(\mathrm{g} \mathrm{SiO}{ }_{2}\right.$ day) with $12 \% \mathrm{C}_{1}$ in $\mathrm{C}_{1}-\mathrm{C}_{4}$. Vanadyl etioporphyrin showed similar catalytic behavior in that silica gel significantly promoted catalytic activity: at $150^{\circ} \mathrm{C}, 2.3 \times 10^{-2} \mathrm{~g} \mathrm{CH}_{4} /(\mathrm{mol} \mathrm{V}$ day $)(87 \%$ $\mathrm{C}_{1}$ in $\mathrm{C}_{1}-\mathrm{C}_{4}$ ).

Very little is known about non-porphyrins except that they can be a major source of transition metals in carbonaceous sediments (Filby and van Berkel, 1987).

Acetylacetonate metal complexes were analyzed in this study because of their potential similarities to the metal complexes in polar resins and asphaltenes (Yen, 1975). Nickel (II) acetylacetonate $\left(\mathrm{Ni}(\mathrm{AcAc})_{2}\right)$ shows high catalytic activity in the conversion of olefins and hydrogen into natural gas, giving $5.4 \times 10^{-4} \mathrm{~g} \mathrm{CH}_{4} /\left(\mathrm{mol} \mathrm{Ni}\right.$ day) at $150^{\circ} \mathrm{C}$ and $2.0 \times 10^{-2} \mathrm{~g}$ $\mathrm{CH}_{4} /\left(\mathrm{mol} \mathrm{Ni}\right.$ day) at $200^{\circ} \mathrm{C}$. Methane through butane are formed almost exclusively with methane the dominant product ( 80 to $98 \%$ ). V(AcAc) 3 showed a much lower selectivity to methane ( 45 to $55 \%$ ) and lost catalytic activity over time (days). The catalytic properties of the early transition metal acetylacetonates are shown in Table 1.

Various transition metal oxides ( $\mathrm{V}, \mathrm{Fe}, \mathrm{Co}$ and $\mathrm{Ni}$ ) have shown catalytic activity but only nickel oxide ( $\mathrm{NiO}$ ) was analyzed in detail and is reported here. It exhibits remarkable catalytic activity, producing natural gas (80 to $90 \%$ methane) and homologous n-alkanes (Fig. 2):

$$
n-C_{x}={ }^{=} H_{2} \rightarrow N G+n-C_{5}+n-C_{6}+\ldots n-C_{x-1}
$$



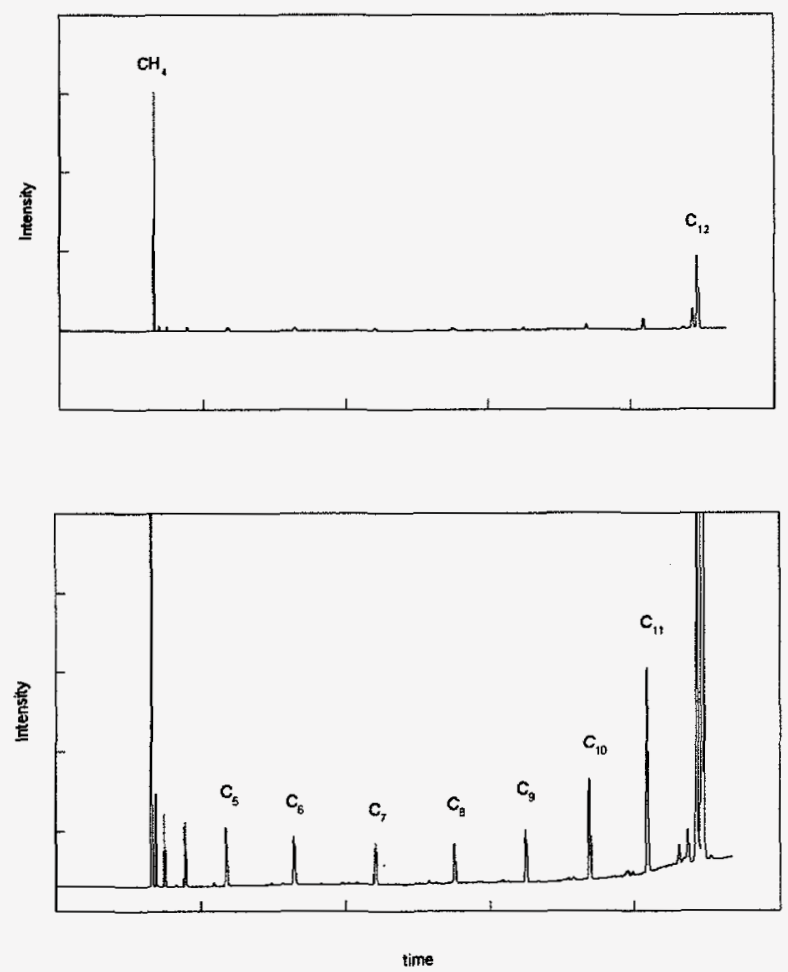

Figure 2

$\mathrm{NiO}$ dispersed on silica gel $\left(\mathrm{NiO} / \mathrm{SiO}_{2}\right)$ (to maximize the concentration of surface catalytic sites) produced $5.5 \mathrm{~g} \mathrm{CH}_{4} /\left(\mathrm{mol} \mathrm{Ni}\right.$ day) at $200^{\circ} \mathrm{C}$ and an Arrhenius analysis showed an activation energy of $49.7 \mathrm{kcal} / \mathrm{mol}$ (Fig. 3). 


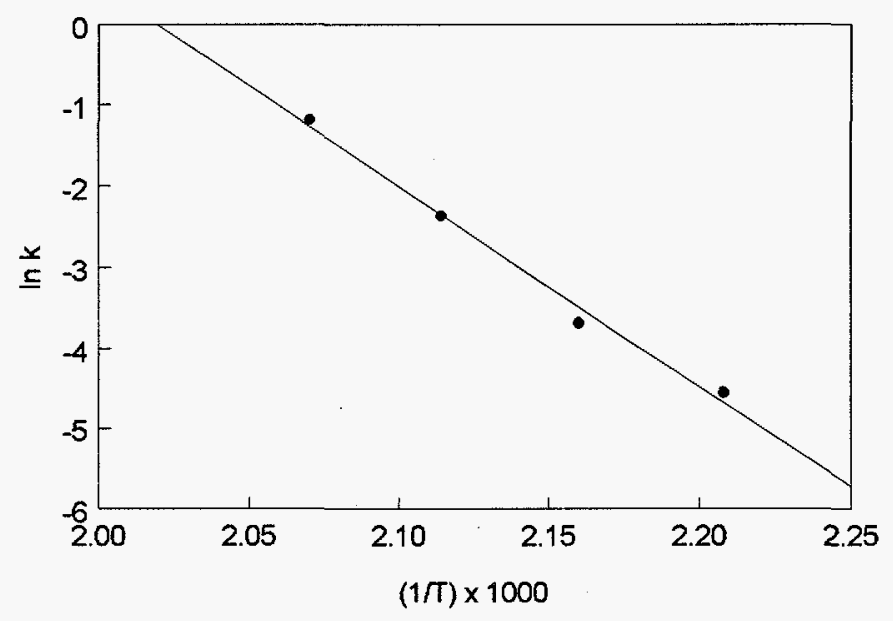

Figure 3

Nickel is genuinely catalytic in these reactions since 1$)$ several moles methane/(mol $\mathrm{Ni)}$ are produced over time with no loss in activity, 2) reaction rates with $\mathrm{NiO} / \mathrm{SiO}_{2}$ are over 10,000 times faster than the same reactions (olefin + hydrogen) with $\mathrm{SiO}_{2}$ alone, and 3) $\mathrm{Ni}$ promotes high specificity to methane: $\sim 90 \%$ (in $\mathrm{C}_{1}-\mathrm{C}_{4}$ ) using $\mathrm{NiO} / \mathrm{SiO}_{2}$ compared to $12 \%$ with $\mathrm{SiO}_{2}$. NiO also proved to be remarkably robust in the presence of typical catalyst poisons: water, air, $\mathrm{CO}$, and $\mathrm{CO}_{2}$ had little or no effect on reaction rates and product specificities.

These results support the contention that transition metals are the catalytic agents in source rocks that generate natural gas (Mango, 1992; Mango et al., 1994). The activity for $\mathrm{NiO} / \mathrm{SiO}_{2}\left(5.5 \mathrm{~g} \mathrm{CH}_{4} /(\mathrm{mol} \mathrm{Ni} \mathrm{d})\right.$ at $\left.200^{\circ} \mathrm{C}\right)$ is essentially the same as that approximated for the source rock $\left(\sim 5.1 \mathrm{~g} \mathrm{CH}_{4} /(\mathrm{mol} \mathrm{Ni} \mathrm{d})\right.$ at $\left.200^{\circ} \mathrm{C}, 160 \mathrm{ppm} \mathrm{Ni}\right)$. Both generate gas that is compositionally indistinguishable from natural gas and clearly distinct from pyrolysis gas (Fig. 4). 


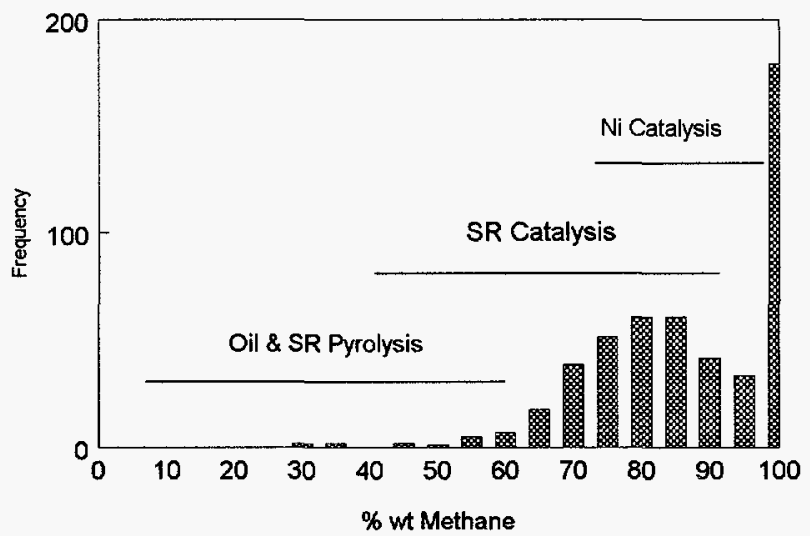

Figure 4

Although porphyrins are a major source of transition metals in carbonaceous deposits (Yen, 1975) it is doubtful that metal porphyrins as such could be the catalytic species in source rocks that generate natural gas. The metal porphyrins analyzed here exhibit only low levels of catalytic activity and unrealistic compositions of gas $(<30 \%$ methane). However, they are dramatically activated by silica gel, yielding natural gas with $>80 \%$ methane. The porphyrins, therefore, could serve two functions in natural sediments: 1) as carriers, delivering transition metals to organic sediments, and 2) as catalysts, activated by various silicates or other mineral oxides.

$\mathrm{Ni}(\mathrm{AcAc})_{2}$ and nickel etioporphyrin are both square planar $\mathrm{d}^{8}$ complexes, yet the acetylacetonate is substantially more catalytic suggesting that oxygen could have an activating effect on nickel. $\mathrm{NiO}$ supports this view in that it is catalytically robust while NiS is totally inactive under the same conditions. The oxide also produces homologous nalkanes (Fig. 2), thus displaying the full breadth of the proposed catalytic process, cleaving all carbon-carbon bonds while showing the predicted specificity for the terminal carbonmethyl bond (Fig. 1; Mango, 1992). Moreover, this remarkable reaction is unattended by thermal cracking, the process usually invoked to explain the presence of mid-range nalkanes in petroleum.

Transition metals are clearly catalytic in the laboratory, but should they be catalytic in the earth, under catagenic conditions? The kinetic data for nickel clearly suggests yes. Consider, for example, the following thermo-catalytic model for oil and gas generation (eqs. 1 and 2): kerogen (K) is thermally converted into olefins (Lewan et al., 1979) by conventional first-order kinetics; the olefins are then either hydrogenated to n-alkanes (OIL, eq. 1) or catalytically converted into natural gas (GAS, eq. 2): 


$$
[\mathrm{K}] \rightarrow\left[\mathrm{n}-\mathrm{C}^{-}+\mathrm{H}_{2}\right]
$$

\section{$\left[\mathrm{Ni}^{*}\right]$ \\ $\rightarrow$ GAS}

(2)

The rate of gas generation is assumed zero-order and controlled by catalyst concentration $\left(\left[\mathrm{Ni}^{*}\right]\right)$ in accordance with the kinetic parameters in Fig. 3. A basin burial model $\left(1^{\circ} \mathrm{C} / \mathrm{Ma}\right)$ is shown in Fig. 5 where the rate of kerogen conversion is controlled by conventional thermal kinetics (Reynolds and Burnham, 1995) while the oil-to-gas ratio is controlled by nickel catalysis at $1 \mathrm{ppm} \mathrm{Ni}$.

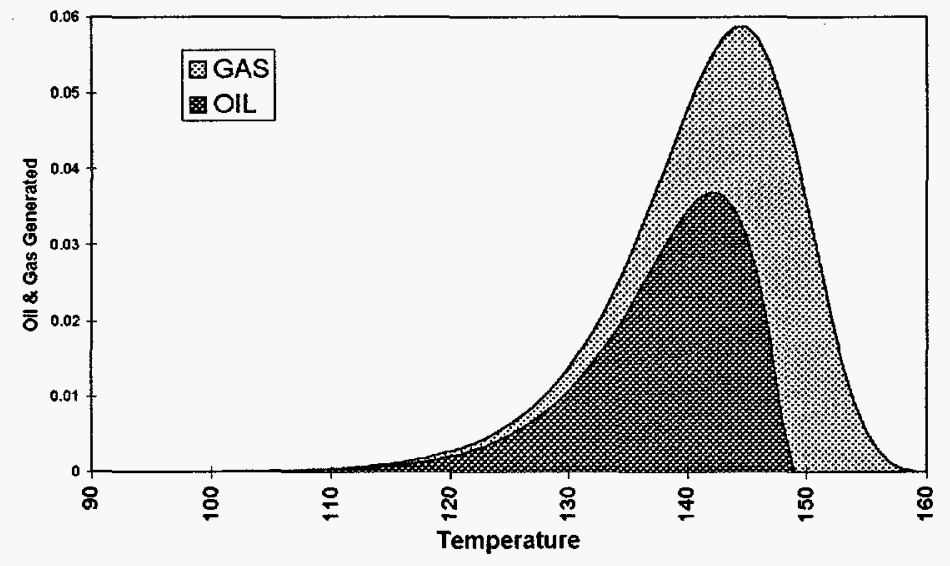

Figure 5

Two features of the model deserve comment. First, because the energy barrier to gas generation is low $(49.7 \mathrm{kcal} / \mathrm{mol})$ compared to kerogen conversion, oil and gas are generated at all maturity levels. This is consistent with the observation that oil and gas are frequently co-deposited in the sub-surface. The model does not include a step where oil is converted to gas, either thermally or catalytically. This is in sharp contrast to conventional models where oil decomposition to gas is often an integral part. Second, the gas-oil ratio increases with maturity, consistent with general observations (Tissot and Welte, 1984), but it is controlled by metal concentrations rather than maturity. For example, the over-all gas yield would increase from $50 \%$ at $1 \mathrm{ppm} \mathrm{Ni}$ to $98 \%$ at $4 \mathrm{ppm}$ $\mathrm{Ni}$ according to the model in Fig. 4. 


\section{CONCLUSIONS}

It has been suggested that the transition metals in source rocks should be catalytic in the generation of natural gas (Mango, 1992). This hypothesis gained support when source rocks were shown to exhibit the predicted activity (Mango et al., 1994), but the role of metals was unclear. Here it is shown that various transition metal compounds in the pure state exhibit identical catalytic properties. Nickel(II) oxide is particularly active, showing essentially the same levels of catalytic activity as seen earlier in source rocks. Transition metals, therefore, are very likely the active agents in source rocks that catalytically generate natural gas in the laboratory. As catalysts, they are remarkably robust. Water, air, $\mathrm{CO}$, and $\mathrm{CO}_{2}$, which are generally powerful poisons in metal catalysis, have little or no effect on the catalytic properties analyzed in this study.

Although nickel oxide may not be a common mineral in source rocks, $\mathrm{NiO} / \mathrm{SiO}_{2}$ is a convenient source of highly dispersed nickel (II) and thus useful for kinetic analysis. It was selected for detailed study because it exhibits catalytic properties similar to other firstrow transition metal oxides, in particular V, Co and Fe. The kinetic parameters in Fig. 3 suggest activity levels for certain nickel compounds but not all. Nickel (II) porphyrins and the sulfide, for example, are inactive. However, silica gel imparts catalytic activity to nickel (II) etioporphyrin and the catalytic properties of the adduct are similar to $\mathrm{Ni}(\mathrm{AcAc})_{2}$ and $\mathrm{NiO}$. A silicate is suggested (e.g., $\left.\mathrm{Ni}(\mathrm{O}-\mathrm{Si}-)_{2}\right)$ which would implicate oxygen as the activating ligand in the three Ni compounds shown to be active in this study.

The model in Fig. 5 approximates the effects of a catalytically active transition metal in catagenesis. However, because active metal concentrations cannot at present be determined, this model should not be viewed as predictive in the generation of oil and gas in the earth. It is unlikely, for example, that the source rocks in our earlier studies contained more than a few ppm active nickel, compared to $150 \mathrm{ppm}$ nickel measured. It can be inferred that some of the nickel compounds typically found in carbonaceous sediments should be catalytic or become catalytic with maturity through interaction with kerogen or mineral oxides. Fig. 5 shows that even 1 ppm active nickel is sufficient to significantly generate gas.

Would olefins and hydrogen be available to active metals under catagenic conditions? Artificial maturation of source rocks would suggest yes. Under open conditions where olefin production can be determined, they constitute over $50 \%$ (vol) of the product (Lewan et al., 1978). Hydrogen is also a major product, constituting up to $50 \%$ of gaseous products (Evans and Felbeck, 1983; Lewan et al., 1978; Harwood, 1977).

Gas-oil ratios tend to increase with depth supporting the popular view that gas is a high maturity product coming from the decomposition of carbonaceous deposits (Tissot and Welte, 1984; Landes, 1967). But giant gas deposits believed to be thermal are found at shallow depths (Galimov, 1988) and oil exists deep in the earth (Price, 1993), exceptions that are not easily explained by conventional ideas. If, however, oil decomposition is not a significant source of natural gas (Mango, 1991, 1987) and metal catalysis is, contradictions like these would not exist. The results presented here indicate that transition metals in source rocks should be active in the catalytic generation of natural gas under catagenic conditions. Because catalytic gas is compositionally identical 
to natural gas while thermal gas is not, catalysis could be a major source of natural gas in the earth.

\section{REFERENCES}

Appleby, W. G., Avery, W. H., and Meerbott, W. K. (1969) Kinetics and mechanism of the thermal decomposition of n-heptane. J. Amer. Chem. Soc. 69, 2279-2285.

Espitalie J., Ungerer P., Irwin I., and Marquis F. (1987) Primary cracking of kerogens. Experimenting and modeling $\mathrm{C} 1, \mathrm{C} 2-\mathrm{C} 5, \mathrm{C} 6-\mathrm{C} 15$ and $\mathrm{C} 15+$ classes of hydrocarbons formed. Org. Geochem. 13, 893-899.

Evans, R. J., and Felbeck, G. T., Jr. (1983) High temperature simulation of petroleum formation-I. The pyrolysis of Green River Shale. Org. Geochem. 4, 135-144.

Fabuss, B. M., Smith, J. O., Lait, R. I., Borsanyi, A. S., and Satterfield, C. N. (1962) Rapid thermal cracking of n-hexadecane at elevated pressures. Ind. Engr. Chem. Proc. Dev. Div. 1, 293-299.

Filby, R. H., and Van Berkel, G. J. (1987) Geochemistry of metal complexes in petroleum, source rocks, and coals: An overview. In Metal Complexes in Fossil Fuels:

Geochemistry, Characterization, and Processing, ACS Symposium Series 344 (Filby, R. H., and Branthaver, J. F. , Eds.; ACS, Washington, DC), 2-39.

Galimov, E. M. (1988) Sources and mechanisms of formation of gaseous hydrocarbons in sedimentary rocks. Chem. Geol. 71, 77-95.

Goebel, E. D., Coveney, R. M., Jr., Angino, E. E., Zeller, E. J., and Dreschhoff, G. A. M. (1984), Oil Gas J. 5 May, 215-222.

Hamak J. E. and Sigler S. (1991) Analyses of natural gases, 1986-90. Information Circular No. 9301 (Bureau of Mines, US Dep. Interior, Pittsburgh).

Harwood, R. J. (1977) Oil and gas generation by laboratory pyrolysis of kerogen. Bull. Amer. Ass. Petrol. Geol. 61, 2082-2102.

Hikita, T., Takahashi, I., and Yoshimichi, T. (1989) Hydropyrolysis of heavy oils. Fuel 68, 1140-1144.

Horsfield B., Schenk H. J., Mills N., and Welte D. H. (1991) An investigation of the inreservoir conversion of oil to gas: compositional and kinetic findings from closed-system programmed-temperature pyrolysis. Org. Geochem. 19, 191-204. 
Landes, K. K. (1967) Eometamorphism, and oil and gas in time and space. Am. Ass. Pet. Geol. Bull. 51, 828-841.

Laidler, K. J., Sagert, N. H., and Wojciechowske, B. W. (1962) Kinetics and mechanisms of the thermal decomposition of propane. Proc. R. Soc. A270, 242-253.

Mango, F. D. (1987) An invariance in the isoheptanes of petroleum. Science 237, 514517.

Mango F. D. (1991) The stability of hydrocarbons under the time-temperature conditions of petroleum genesis. Nature 352, 146-148.

McNab, J. G., Smith, P. V., Jr., and Betts, R. L. (1952) The evolution of petroleum. Ind. and Engr. Chem. 44, 2556-2563.

McNeil, R. I., and BeMent, W. O. (1996) Thermal stability of hydrocarbons: Laboratory criteria and field examples. Energy \& Fuels 10, 60-70.

Price, L. C., and Schoell, M. (1995) Constraints on the origins of hydrocarbon gas from compositions of gases at their site of origin. Nature 378, 3680371 .

Price L. C. (1993) Hydrocarbon thermal stability in nature: Limits, evidence, characteristics, and possible controls. Geochim. Cosmochim. Acta. 57, 3261-3280.

Reynolds, J. G., and Burnham, A. K. (1995) Comparison of kinetic analysis of source rocks and kerogen concentrates. Org. Geochem. 23, 11-19.

Saxby J. D. and Riley K. W. (1984) Petroleum generation by laboratory-scale pyrolysis over six years simulating conditions in a subsiding basin. Nature 308, 177-175.

Schoell M. (1980) The hydrogen and carbon isotopic composition of methane from natural gas of various origins. Geochim. Cosmochim. Acta. 44, 649-661.

Shock, E. L. (1994) Catalyzing methane production. Nature 368, 499-500.

Tissot B. P. and Welte D. H. (1984) Petroleum Formation and Occurrence, pp. 69-267. Springer-Verlag.

Treibs, A. (1934) Chlorophyll und haminderivate in bituminosen gesteinen, erdolen und asphalten. Annalen Chemie 510, 42-62.

Yen, T. F. (1975) Chemical aspects of metals in native petroleum. In The Role of Trace Metals in Petroleum. pp. 1-30. Ann Arbor Science Publishers Inc., Ann Arbor. 


\section{Table}

Table 1. The catalytic properties of various transition metal acetylacetonates (AcAc) in the conversion of n-octadecene- 1 and hydrogen into natural gas $\left(200^{\circ} \mathrm{C}\right)$. Reactions were carried out in $6 \mathrm{ml}$ glass reactors under hydrogen (1 atm) using $\sim 1 \mathrm{gm}$ of the acetonates and $.2 \mathrm{ml}$ olefin. The rates are in $\mathrm{g}$ methane/(mol metal day) and $\% \mathrm{C}_{1}$ in $\%$ by wt methane in $\mathrm{C}_{1}-\mathrm{C}_{4}$. The metal acetonates were used as bulk solids. Thus the concentrations of surface metal (g surface metal/g solid) varied according to the bulk state of the compounds. The rate constants were not maximized by dispersing the solids to optimum surface areas; they should be viewed, therefore, as minimum values intended for comparative use only.

Metal Acetylacetonates

$\mathrm{Ni}(\mathrm{AcAc})_{2}$

$\mathrm{Fe}(\mathrm{AcAc})_{3}$

$\mathrm{V}(\mathrm{AcAc})_{3}$

$\mathrm{Co}(\mathrm{AcAc})_{2}$

$\mathrm{Cr}(\mathrm{AcAc})_{3}$

$\mathrm{Mn}(\mathrm{AcAc})_{2}$ g Methane/(mole Metal d)

$2.0 \times 10^{-2}$

$1.8 \times 10^{-2}$

$6.9 \times 10^{-3}$

$5.9 \times 10^{-3}$

$3.1 \times 10^{-4}$

$4.8 \times 10^{-5}$
$\% \mathrm{C}_{1}$

$80-97$

76

47

45

58

30 


\section{Figure}

Fig. 1. The catalytic scheme proposed for the hydrogenolysis of a long-chain n-alkene to methane (Mango, 1992). The wavy line denotes a long carbon chain of any length and the wavy line truncated by a double bond represents an $\alpha$-olefin. The arrow from the double bond to the metal $(\mathrm{M})$ indicates a weak coordinate bond between the metal and the double bond. The metal maintains a $\sigma$ bond (indicated by a solid line) in each of the four intermediates in the figure: to $\mathrm{H}$ in the lower left quadrant, to the number two carbon of the alkyl chain (upper left), to the number three carbon of the alkyl chain (upper right), and to $\mathrm{CH}_{3}$ (lower right). The metal is free to move up or down the carbon chain by sequential addition-elimination steps. Thus, the scheme applies to the generation of ethane and higher alkanes by moving $M$ to the number four and higher carbon atoms (e.g., an ethyl group is substituted for the methyl group in the lower right quadrant when $M$ is $\sigma$ bonded to the number four carbon of the chain in the upper right). Because of the relative stability of the metal-methyl intermediate, this mode of gas generation predicts a gas product enriched in methane (Mango, 1992).

Fig. 2. Gas chromatogram (gc) of the product from n-dodecene-1, hydrogen and solid $\mathrm{NiO}\left(200^{\circ} \mathrm{C}, 24 \mathrm{hr}\right.$.). The reactions were carried out in glass U-tubes $(6 \mathrm{ml}, 2.5 \mathrm{~g} \mathrm{NiO})$ in a continuous reactor mode at steady-state $(0.489 \mathrm{ml}$ hydrogen $/ \mathrm{min})$; methane was generated at $4.95 \times 10^{-2} \mathrm{~g} /(\mathrm{mol} \mathrm{Ni}$ day). This rate and those quoted for the porphyrins and acetylacetonates are for comparative purposes only. They should be viewed as lower limits since the compounds were used in bulk form with no attempt to maximize metal surface area $(\mathrm{a} / \mathrm{g})$ and thus maximize activity. The total product is shown in the upper gc. The lower gc is the same product at a higher sensitivity to display the homologous nalkanes.

Fig. 3. An Arrhenius plot for the reaction of n-octadecene-1 and hydrogen over nickel oxide supported on silica gel. The catalyst was prepared by dispersing nickel nitrate on silica gel and then thermally decomposing the nitrate to nickel oxide (Bhattacharyya and Vir, 1957). A solution ( $150 \mathrm{ml})$ of nickel (II) nitrate (hexahydrate) $(4.8 \mathrm{~g}$ ) was added to $100 \mathrm{ml}$ silica gel ( 60 to $200 \mathrm{mesh}$ ) and the resulting mixture evaporated to a thick slurry at $70^{\circ}$ and then oven-dried in air for $24 \mathrm{hr}\left(80^{\circ} \mathrm{C}\right)$. The product $(2.6 \%$ by wt Ni) was activated in flowing hydrogen at $400^{\circ} \mathrm{C}$ for $24 \mathrm{~h}$ prior to the kinetic runs. Experiments were carried out between 180 and $210^{\circ} \mathrm{C}$. Reactions were conducted in $6 \mathrm{ml} \mathrm{U}$-tube flow-reactors at steady-state $\left(\sim 1 \mathrm{cc} \mathrm{H}_{2} / \mathrm{min}\right)$. The units for $\mathrm{k}$ are $\mathrm{g}$ methane/(g Ni day). Regression equation: $\ln \mathrm{k}=-24833(1 / \mathrm{T})+50.145 ; \mathrm{R}^{2}=0.991$

Fig. 4. Histogram of methane concentrations in natural gas ( $\%$ by wt in $\left.\mathrm{C}_{1}-\mathrm{C}_{4}\right)$ compiled from a US Dept. of Interior database (Hamak and Sigler, 1991). The horizontal lines indicate the compositional regions for gas products from the indicated processes: Oil \& SR Pyrolysis: taken from reported products of oil and kerogen pyrolysis experiments (Horsfield et al., 1991; Espitalie et al., 1987; Saxby and Riley, 1984; Evans and Felbeck, 1983; McNab et al., 1952). SR Catalysis: from experiments using a Monterey source 
rock (Miocene) described in Mango et al., (1994). Ni Catalysis: from the nickel compounds in this report.

Fig. 5. Oil and gas generation curves for a source rock containing $1 \mathrm{ppm}$ nickel. The fraction of kerogen converted $(\mathrm{x})$ was calculated for time intervals of 1 Ma using first order kinetics: $x=a(1-\exp (-k t))$, where $t=1 \mathrm{Ma}$ and (a) is the fraction of unreacted kerogen; the rate constant $\mathrm{k}$ was calculated for each temperature with $\mathrm{E}=53.7 \mathrm{kcal} / \mathrm{mol}$ and $\mathrm{A}=7.5 \times 10^{13} 1 / \mathrm{s}$ (from Reynolds and Burnham (1995) for a Green River shale ). The model simulates a geologic heating rate $=1^{\circ} \mathrm{C} / \mathrm{Ma}$. The portion of $\mathrm{x}$ going to gas $(\mathrm{g})$ was calculated using zero-order kinetics: $\mathrm{g}=\mathrm{kt}$, where $\mathrm{k}$ was calculated from the curve in Fig. $3, E=49.7 \mathrm{kcal} / \mathrm{mol}$ and $A=6.9 \times 10^{16} 1 / \mathrm{s}$. The oil (o) generated for each $1 \mathrm{Ma}$ interval was calculated by difference $(\mathrm{o}=\mathrm{x}-\mathrm{g})$. For $(\mathrm{x}-\mathrm{g})<0$, o was set to 0 and $\mathrm{x}=\mathrm{g}$. The integral for the outer curve $(0+g)$ is one. 